\title{
Epidermal growth factor enhances osteogenic differentiation of dental pulp stem cells in vitro
}

\author{
Casiano Del Angel-Mosqueda1,2,4, Yolanda Gutiérrez-Puente, ${ }^{2,3}$, Ada Pricila López-Lozano 1,2,4, \\ Ricardo Emmanuel Romero-Zavaleta ${ }^{1}$, Andrés Mendiola-Jiménez ${ }^{5}$, Carlos Eduardo Medina-De la Garza 1,5, \\ Marcela Márquez-M $M^{5,6}$ and Myriam Angélica De la Garza-Ramos ${ }^{1,4^{*}}$
}

\begin{abstract}
Introduction: Epidermal growth factor (EGF) and basic fibroblast growth factor (bFGF) play an important role in extracellular matrix mineralization, a complex process required for proper bone regeneration, one of the biggest challenges in dentistry. The purpose of this study was to evaluate the osteogenic potential of EGF and bFGF on dental pulp stem cells (DPSCs).

Material and methods: Human DPSCs were isolated using CD105 magnetic microbeads and characterized by flow cytometry. To induce osteoblast differentiation, the cells were cultured in osteogenic medium supplemented with EGF or bFGF at a low concentration. Cell morphology and expression of CD146 and CD10 surface markers were analyzed using fluorescence microscopy. To measure mineralization, an alizarin red $S$ assay was performed and typical markers of osteoblastic phenotype were evaluated by RT-PCR.
\end{abstract}

Results: EGF treatment induced morphological changes and suppression of CD146 and CD10 markers. Additionally, the cells were capable of producing calcium deposits and increasing the MRNA expression to alkaline phosphatase (ALP) and osteocalcin $(\mathrm{OCN})$ in relation to control groups $(p<0.001)$. However, bFGF treatment showed an inhibitory effect.

Conclusion: These data suggests that DPSCs in combination with EGF could be an effective stem cell-based therapy for bone tissue engineering applications in periodontics and oral implantology.

Keywords: Dental pulp stem cells, Epidermal growth factor, Basic fibroblast growth factor, Osteogenic differentiation, Bone mineralization, Bone remodelling

\section{Introduction}

The multi-lineage differentiation capacity of mesenchymal stem cells (MSCs) has been amply studied in recent years because of its implication in tissue engineering and regenerative medicine $[1,2]$; however, this field is currently faced with the critical challenge of developing novel approaches to regenerate large bone defects. Some years ago, Gronthos and colleagues isolated dental pulp stem cells (DPSCs) from human third molars confirming that these cells present the ability to differentiate into

\footnotetext{
* Correspondence: myriam.garzarm@uanl.edu.mx

'Unidad de Odontología Integral y Especialidades, Centro de Investigación y Desarrollo en Ciencias de la Salud, Universidad Autónoma de Nuevo León, Monterrey, Nuevo León, México

${ }^{4}$ Facultad de Odontología, Universidad Autónoma de Nuevo León, Monterrey, Nuevo León, México

Full list of author information is available at the end of the article
}

odontogenic/osteogenic cells [3-5]. Previous reports have shown that the osteogenic differentiation on DPSCs is successfully induced by chemical cues such as dexamethasone, ascorbic acid, and $\beta$-glycerophosphate [6-8]. Although these compounds have proven efficacy, analysis of the role of growth factors in osteogenesis has been the aim of several studies focused on improving extracellular matrix mineralization, a physiological process characterized by high expression of alkaline phosphatase (ALP) and osteocalcin (OCN), followed by calcium deposition $[9,10]$.

Epidermal growth factor (EGF) and basic fibroblast growth factor (bFGF) are powerful mitogens for many cell types including MSCs [11-13]. Ideally, it is expected that these factors maintain the self-renewal and multipotency capacities of these cells [14] but it is known that they can also promote differentiation towards specialized 
lineages such as osteoblasts, a process largely controlled by various growth factors $[15,16]$. Certain studies show that bFGF affects osteogenic differentiation of DPSCs [17] through inhibition of ALP enzymatic activity and mineralization [18]. This effect has also been shown in stem cells from human exfoliated deciduous teeth (SHED) and periodontal ligament stem cells (PDLSCs) $[19,20]$. On the other hand, it is well-known that an extensive variety of mesenchymal cells normally express the epidermal growth factor receptor (EGFR), a tyrosine kinase receptor that activates intracellular signalling pathways that determine their fate [21-23]. Emerging evidence suggests that EGF works as an enhancer of mineralization during differentiation of MSCs derived from bone marrow [24, 25]; however, the effect of EGF on osteogenic differentiation of DPSCs is unknown.

The purpose of this study was to evaluate the role of EGF and bFGF in order to identify crucial growth factors associated with enhancing osteogenic differentiation of DPSCs. We hypothesized that EGF supplementation may increase mineralization on the osteogenic differentiation of these cells. Our results provide evidence that EGF treatment, but not bFGF, is capable of increasing calcium deposit formation as well as ALP and OCN gene expression compared to traditional osteogenic medium. These observations indicate that EGF could be an effective adjuvant for improving bone regeneration in periodontics and oral implantology.

\section{Material and methods Subjects}

Pulp samples were obtained from 12 human premolars extracted for orthodontic purposes from healthy patients; finally, the dental pulp tissues of the youngest patient (18 years of age) were used. The protocol was approved by the Ethics Committee, School of Dentistry of the Universidad Autónoma de Nuevo León (UANL) and performed in accordance with the ethical standards laid down in the 1964 Declaration of Helsinki. Informed consent was obtained from all donors.

\section{Cell culture}

Dental pulp explants were digested with $3 \mathrm{mg} / \mathrm{ml}$ collagenase type I and $4 \mathrm{mg} / \mathrm{ml}$ dispase (Sigma-Aldrich, St. Louis, MO, USA) at $37{ }^{\circ} \mathrm{C}$ for $1 \mathrm{~h}$. The cell suspension was centrifuged at $300 \mathrm{~g}$ for $10 \mathrm{~min}$, washed and then filtered through a $70 \mu \mathrm{m}$ nylon filter (BD Biosciences, San Jose, CA, USA). Dental pulp cells were maintained in $\alpha$-modified Eagle's medium ( $\alpha$-MEM) supplemented with $10 \%$ fetal bovine serum (FBS) (Gibco-Invitrogen, Carlsbad, CA, USA), $2 \mathrm{mM}$ L-glutamine, $100 \mathrm{U} / \mathrm{ml}$ penicillin, $100 \mu \mathrm{g} / \mathrm{ml}$ streptomycin and $0.25 \mu \mathrm{g} / \mathrm{ml}$ amphotericin B (Sigma-Aldrich) at $37{ }^{\circ} \mathrm{C}$ in a humidified atmosphere with $5 \% \mathrm{CO}_{2}$ for 3 weeks. The medium was renewed every 3 days.

\section{Magnetic cell sorting}

Cell isolation was performed following the manufacturer's protocol. Briefly, cultured cells were resuspended in PBS with $1 \%$ bovine serum albumin (BSA) (SigmaAldrich) and then incubated with CD105 magnetic microbeads (Miltenyi Biotech, Bergish Gladbach, Germany) for $15 \mathrm{~min}$ at $4{ }^{\circ} \mathrm{C}$. Cells were washed and loaded into a MS column placed in the magnetic field of a MiniMACS $^{\text {TM }}$ Separator (Miltenyi Biotech). Magneticallylabelled cells were collected and subcultured until passage 3 under the same growth conditions.

\section{Flow cytometry analysis}

To confirm the typical MSC immunophenotype, magneticisolated cells were incubated with the following monoclonal antibodies: CD105-FITC, CD73-PE, CD13-PE, CD45-FITC, CD34-PE, HLA-DR-PerCp, CD14-PE, CD11b-PE (BD Biosciences) and CD90-FITC (Miltenyi Biotech). Antibodies were added to $\sim 1 \times 10^{5}$ cells per sample and then incubated for $30 \mathrm{~min}$ at $4{ }^{\circ} \mathrm{C}$ in dark. Stained cells were washed and then resuspended in PBS with $4 \%$ paraformaldehyde. All samples were analyzed in a FACSCalibur ${ }^{\text {Tn }}$ flow cytometer system (BD Biosciences).

\section{Formalin-induced fluorescence assay}

DPSCs were plated onto 6-well plates (Corning-Costar, Corning, NY, USA) at a density of $\sim 3 \times 10^{4}$ per well and cultured for 7 days in $\alpha$-MEM as a negative control, and osteogenic medium (OM) as a positive control, composed of $\alpha$-MEM, $10^{-7} \mathrm{M}$ dexamethasone, $50 \mu \mathrm{g} / \mathrm{ml}$ ascorbic acid and $10 \mathrm{mM} \beta$-glycerophosphate (SigmaAldrich). At the same time, cells were incubated with OM containing $10 \mathrm{ng} / \mathrm{ml}$ of human EGF (OM + EGF) (Miltenyi Biotech) and $\mathrm{OM}$ containing $10 \mathrm{ng} / \mathrm{ml}$ of human bFGF (OM + bFGF) (Life Technologies, Rockville, MD, USA). Cultured cells were washed and then fixed with $10 \%$ neutral-buffered formalin (BDH Chemicals, Ltd, UK) for $30 \mathrm{~min}$. Fixed cells were incubated with $1 \mu \mathrm{g} / \mathrm{ml}$ DAPI (Thermo Scientific, Waltham, MA, USA) at room temperature for $5 \mathrm{~min}$ in dark. Cells were analyzed in a Zeiss Axiovert $200 \mathrm{M}$ fluorescence microscope (Carl Zeiss, Göttingen, Germany).

\section{Immunocytochemistry}

DPSCs were plated onto 8-well chamber slides (Lab-Tek Chamber Slide, Nunc, Germany) at a density $\sim 2.5 \times 10^{3}$ per well and maintained in $\alpha-M E M, O M, O M+E G F$ and $\mathrm{OM}+\mathrm{bFGF}$ for 7 days. Cultured cells were fixed with cold methanol for $10 \mathrm{~min}$ and then incubated in PBS with $2 \%$ BSA at room temperature for $30 \mathrm{~min}$. 
Fixed cells were incubated with mouse anti-human CD146-FITC (Miltenyi Biotech) and mouse anti-human CD10-FITC (BD Biosciences) monoclonal antibodies, counterstained with DAPI and then analyzed by fluorescence microscopy.

\section{Osteogenic differentiation}

DPSCs were plated onto 24-well plates (Corning-Costar) at a density of $\sim 6 \times 10^{3}$ cells per well and cultivated in $\alpha$-MEM for $24 \mathrm{~h}$. The DPSCs were washed and then maintained in different culture media: $\alpha$-MEM, OM, $\mathrm{OM}+\mathrm{EGF}$ and $\mathrm{OM}+\mathrm{bFGF}$ at $37{ }^{\circ} \mathrm{C}$ in a humidified atmosphere with $5 \% \mathrm{CO}_{2}$ for 21 days. All media were renewed every 3 days.

\section{Alizarin red S assay}

After 21 days of osteogenic induction, the cells were fixed with $10 \%$ neutral-buffered formalin for $30 \mathrm{~min}$. Fixed cells were washed and then incubated with $2 \%$ alizarin red $\mathrm{S}$ (ARS) ( $\mathrm{pH}$ 4.2) (Sigma-Aldrich) at room temperature for $30 \mathrm{~min}$ in dark with gentle shaking. After staining, they were washed 4 times with PBS. The cells were analyzed by light microscopy and then incubated with cetylpyridinium chloride (CPC) $100 \mathrm{mM}$ at $37{ }^{\circ} \mathrm{C}$ for $1 \mathrm{~h}$ to solubilize the extracellular calcium deposits attached to ARS. Two hundred microliters of each sample were transferred onto 96-well black plates (Corning-Costar). The ARS concentration was determined by absorbance at $495 \mathrm{~nm}$ in an iMark $^{\mathrm{TM}}$ Absorbance Microplate Reader (Bio-Rad, Hercules, CA, USA) [26].

Reverse transcriptase polymerase chain reaction (RT-PCR) Total RNA from DPSCs, cultured in $\alpha$-MEM, OM, $\mathrm{OM}+\mathrm{EGF}$ and $\mathrm{OM}+\mathrm{bFGF}$ was isolated using the TRIzol method (Invitrogen Corp, Carlsbad, CA, USA). For the cDNA synthesis, the ImProm-II Reverse Transcription System kit (Promega, Madison, WI, USA) was used according to the manufacturer's instructions. PCR reactions to $\beta$-actin, alkaline phosphatase (ALP), bone sialoprotein (BSP), osteocalcin (OCN) and osteopontin (OPN) were performed in a MJ-Mini ${ }^{\mathrm{TM}}$ Staff Thermal cycler (Bio-Rad), following the protocol previously described [27]. PCR products were resolved on $1.5 \%$ agarose gel electrophoresis, running at $100 \mathrm{~V}$ for $35 \mathrm{~min}$. The gels were stained with $1 \mu \mathrm{g} / \mathrm{ml}$ ethidium bromide (Bio Basic Inc, Markham, ON, Canada) and displayed in a UV Transilluminator $\operatorname{Doc}^{\text {TM }}$ Gel (Bio-Rad). All the reagents were used as a negative control for PCR except cDNA. In our study, all tests were performed three times (Table 1 ).

\section{Statistical analysis}

The ARS levels were analyzed using one-way analysis of variance (ANOVA) and Tukey's test for multiple
Table 1 Primer sequences for osteogenic differentiation analysis using reverse transcriptase-polymerase chain reaction (RT-PCR)

\begin{tabular}{|c|c|c|}
\hline Gene & Sequence of oligonucleotides $\left(5^{\prime}-3^{\prime}\right)$ & $\operatorname{Tm}{ }^{\circ} \mathrm{C}$ \\
\hline$\overline{\beta-A c t i n}$ & $\begin{array}{l}\text { Forward: GGCATCCTGACCCTGAAGTA } \\
\text { Reverse: GGGGTGTTGAAGGTCTCAAA }\end{array}$ & 51 \\
\hline OCN & $\begin{array}{l}\text { Forward: GAGCCCCAGTCCCCTACC } \\
\text { Reverse: CCGATAGAGGTCCTGAAAG }\end{array}$ & 58 \\
\hline BSP & $\begin{array}{l}\text { Forward: CAGCGGAGGAGACAATGGAG } \\
\text { Reverse: TTCAACGGTGGTGGTITCC }\end{array}$ & 58 \\
\hline OPN & $\begin{array}{l}\text { Forward: CAACGAAAGCCATGACCACA } \\
\text { Reverse: CAGGTCCGTGGGAAAATCAG }\end{array}$ & 54 \\
\hline ALP & $\begin{array}{l}\text { Forward: GGTGAACCGCAACTGGTACT } \\
\text { Reverse: CCCACCTGGGTGTAGTCAT }\end{array}$ & 54 \\
\hline
\end{tabular}

comparisons among groups and $p$-values $<0.01$ were considered statistically significant in all treatments. Data analysis was performed with SPSS software (SPSS Inc, Chicago, IL, USA).

\section{Results}

Isolation and phenotypic characterization of DPSCs

Adherent unsorted cells showed different sizes and morphologies after 3 weeks under cell growth conditions (Fig. 1a), in contrast, CD $105^{+}$magnetically-sorted cells showed a relatively homogeneous morphology characterized by spindle-shaped appearance with oval-central nuclei. Additionally, several colony-forming unit fibroblasts (CFU-F) were observed until passage 3 (Fig. 1b-d). Sorted cells had positive or negative expression by flow cytometry to the following surface markers: $99.47 \%$ CD105-FITC, 97.89 \% CD73-PE, 85.03 \% CD90-FITC, $86.76 \%$ CD13-PE, 0 \% CD45-FITC, $0.11 \%$ CD34-PE, $0.02 \%$ HLA-DR-PerCp, $0.38 \%$ CD14-PE and $0.39 \%$ CD11b-PE (Fig. 1e). These results confirm that our cell culture presented the typical MSC immunophenotype:

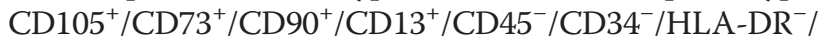
$\mathrm{CD}^{-} 4^{-} / \mathrm{CD}_{11 \mathrm{~b}^{-}}$.

\section{Morphological changes and expression of CD146 and CD10 surface markers}

After 7 days in $\alpha$-MEM incubation, DPSCs showed a fibroblastic-elongated morphology and tended to align themselves in parallel lines (Fig. 2a). Similar cell morphology was also observed in OM treated-cells (Fig. 2b). However, DPSCs in OM + EGF treatment showed clear morphological differences, characterized by polygonalshaped appearance with spherical-peripheral nuclei and low cytoplasm content (Fig. 2c); moreover, these changes in $\mathrm{OM}+\mathrm{bFGF}$ treatment were not observed (Fig. 2d). Additionally, the presence of EGF seems to induce a different organization pattern in cell culture, in comparison to the OM group. The highest cell confluence was observed in cells incubated with EGF or bFGF, in relation to $\alpha-M E M$ and $O M$ control groups. Immunofluorescence 


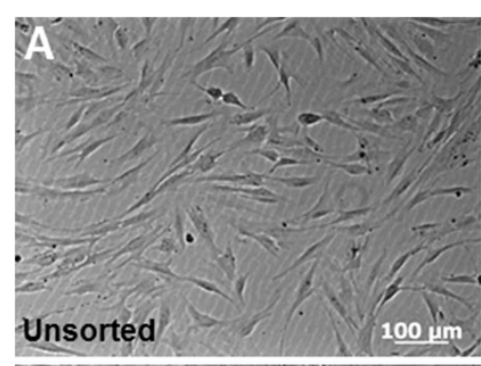

\section{E}
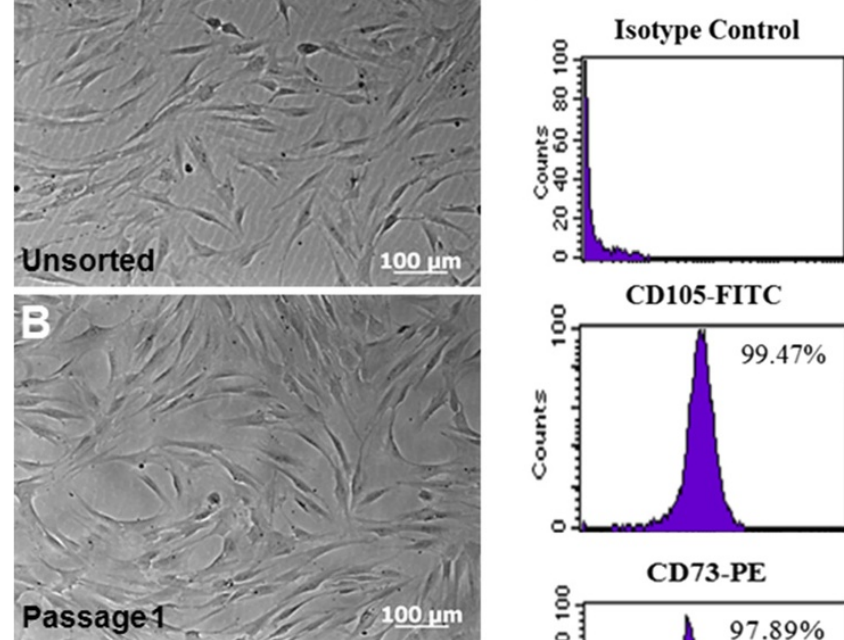

CD105-FITC

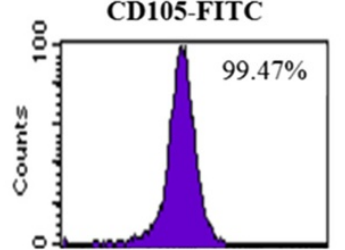

CD73-PE

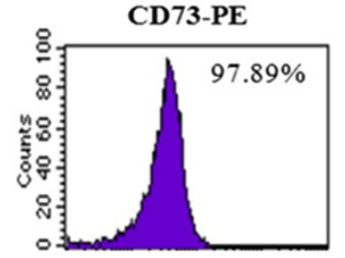

CD90-FITC
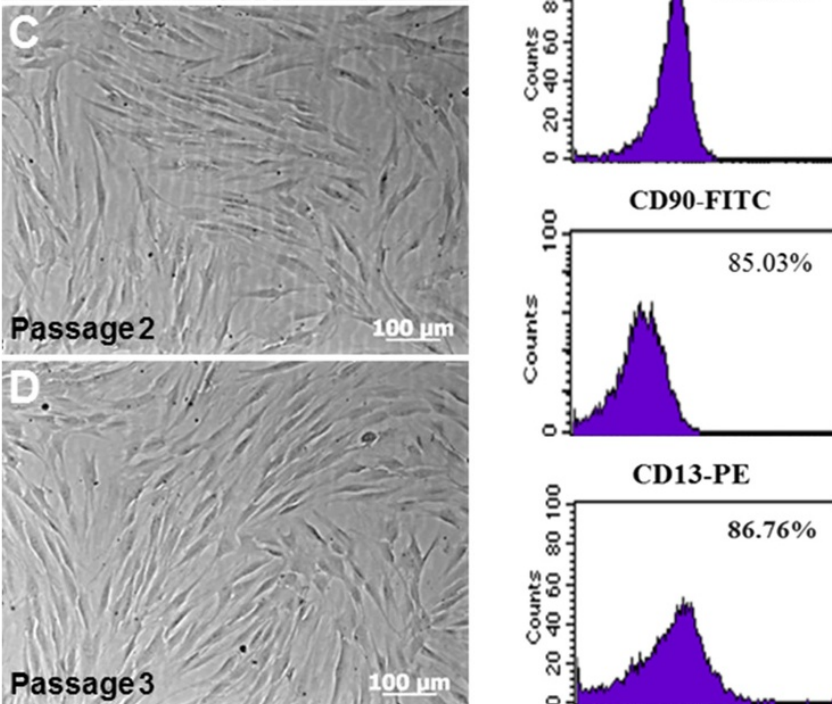

CD13-PE
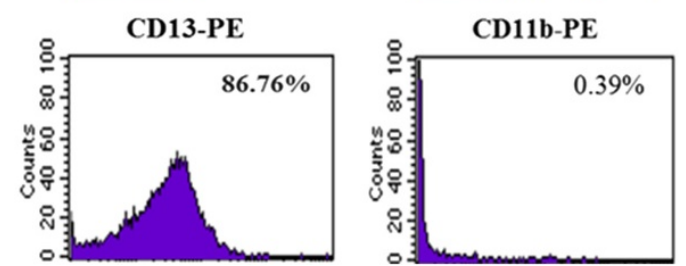

Fig. 1 Cell culture and flow cytometry analysis of isolated dental pulp stem cells (DPSCs). a Representative phase-contrast micrographs shows unsorted-cells derived from human dental pulp tissue after 14 days of cell culture. $\mathbf{b}-\mathbf{d}$ CD $105^{+}$magnetically-sorted DPSCs cultured in a-MEM without osteogenic induction. Morphologically, cells appear as typical fibroblastic and spindle shape during 3 passages. Original magnification 10x, scale bar $=100 \mu \mathrm{m}$. e Flow cytometric analysis presented as histograms that show cell fluorescence intensity on the horizontal axis and cell frequency distribution on the vertical axis. Percentage results show positive expression to immunophenotype associated with mesenchymal stem cell (MSC) lineage as well as a lack of expression for hematopoietic markers

analysis confirmed that cells cultivated in $\alpha$-MEM for 7 days were highly positive to CD146 and CD10 surface markers (Fig. 2e, i). Although, the OM group was capable of decreasing expression of both markers (Fig. 2f, j), EGF treated-cells showed the strongest inhibitory effect (Fig. 2g, k). In contrast, bFGF treated-cells seem to maintain expression levels in relation to $\alpha$-MEM group (Fig. 2h, l).

\section{Extracellular calcium deposition by ARS assay}

After 21 days under osteogenic induction, a complete cell confluence in all treatments was observed. At this stage, the $\alpha$-MEM group was negative to ARS $(18.81 \mu \mathrm{g} / \mathrm{ml})$; however, in $\mathrm{OM}, \mathrm{OM}+\mathrm{EGF}$, and $\mathrm{OM}+\mathrm{bFGF}$ treatments, calcium deposition were observed (Fig. 3a). Microscopic analysis confirmed the absence of mineralized nodules in $\alpha$-MEM (Fig. $3 b)$. DPSCs treated only with OM showed high levels of ARS $(792.64 \mu \mathrm{g} / \mathrm{ml})$ and prominent mineralization nodules (Fig. 3c). Interestingly, OM supplemented with EGF induced a clear increase in abundance and size of calcium deposits (Fig. 3d), in addition to a significant increase in the mineralization levels evaluated by ARS $(1686.31 \mu \mathrm{g} / \mathrm{ml})$, in comparison to OM control group (Fig. 3f). In contrast, supplementation with bFGF showed a statistical 


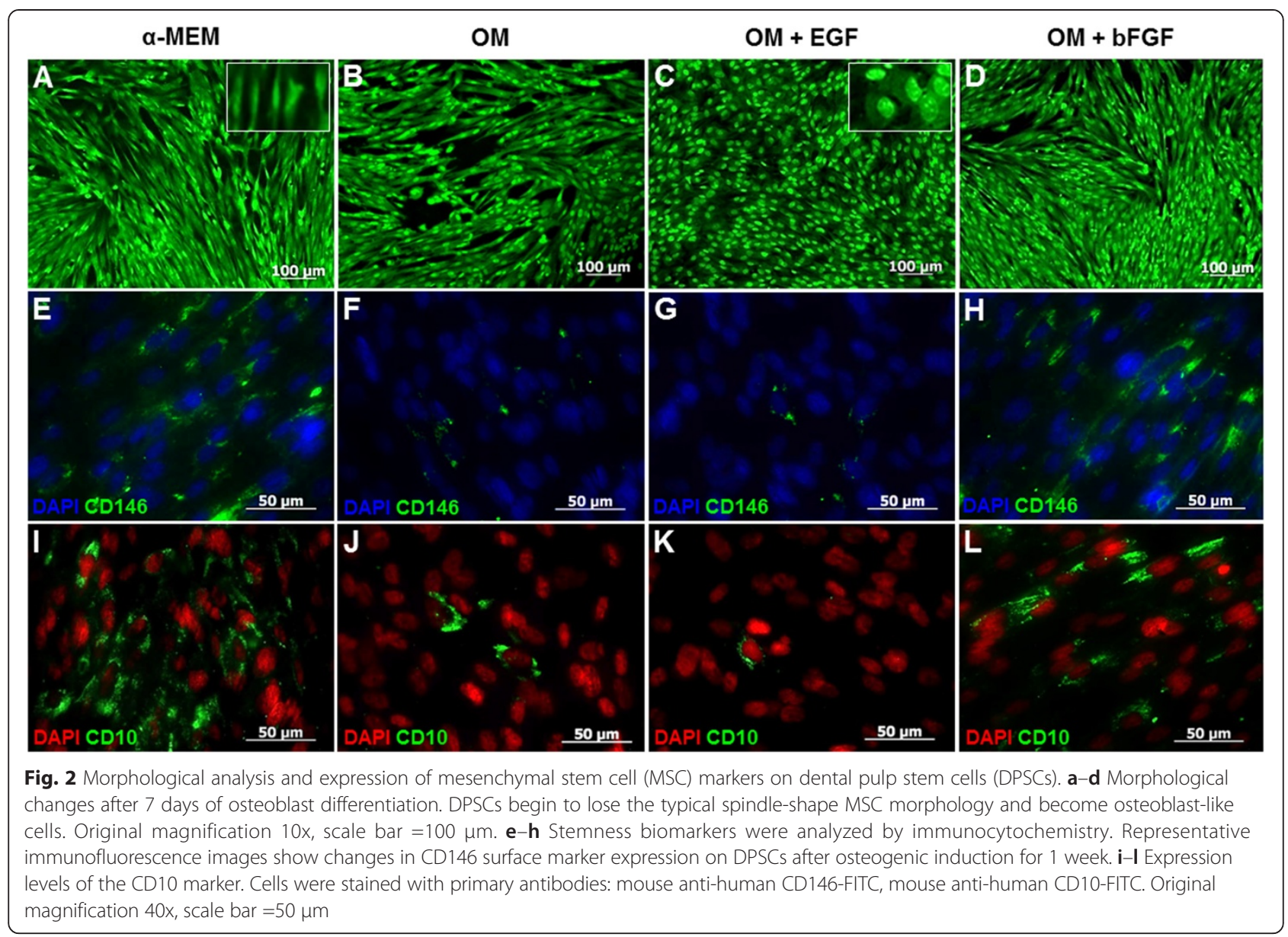

difference with ARS $(174.87 \mu \mathrm{g} / \mathrm{ml})$ with respect to $\mathrm{OM}$ or $\mathrm{OM}+\mathrm{EGF}$, but the number of mineralized nodules were fewer than OM, suggesting an inhibitory effect (Fig. 3e).

\section{Gene expression by RT-PCR}

After 21 days of cell culture, gene expression of OCN was negative in the $\alpha$-MEM group. In addition, the OM group was positive for this osteoblast-phenotypic marker; however, its expression level was superior due to the presence of EGF in the culture medium, suggesting its importance during osteogenesis. Contrary to these effects, the addition of bFGF resulted in a decrease in BSP, OCN and OPN expression with respect to OM treated-cells (Fig. 3g).

\section{Discussion}

Growth factors are recognized for their active participation in many biological processes such as cell migration, proliferation and differentiation $[11,28]$. In the osteogenic context, it is also known that some of these factors play an essential role in bone regeneration since they are responsible for triggering cell specific signalling pathways that allow expression of bone morphogenetic proteins (BMPs), which are molecules centrally involved in extracellular matrix mineralization and damage bone repair [29-31].

Our results provide evidence that supplementation with EGF enhances osteogenic mineralization on DPSCs during cell differentiation, suggesting its important role in favoring this cell fate. EGF and bFGF supplementation is commonly used to ensure survival and proliferation of MSCs cultured under serum-free conditions [32-34]; however, recent studies suggest that EGF added to traditional osteogenic medium not only promotes cell proliferation but also enhances mineralization of MSCs derived from bone marrow [24, 25, 35]. We have found that DPSCs are an excellent alternative to use instead of bone marrow for cell therapy; however, a challenge to overcome is the small amount of dental pulp tissue obtained; it is for this reason that in our study the cells were obtained from human premolars extracted for orthodontic purposes.

It is known that growth factors such as IGF-1, TGF- $\beta$ and TNF- $\alpha$ enhance osteogenic differentiation of DPSCs [36-38]. Additionally, a recent study showed that 12 or $24 \mathrm{~h}$ of EGF treatment enhanced chemokine IL-8 and 


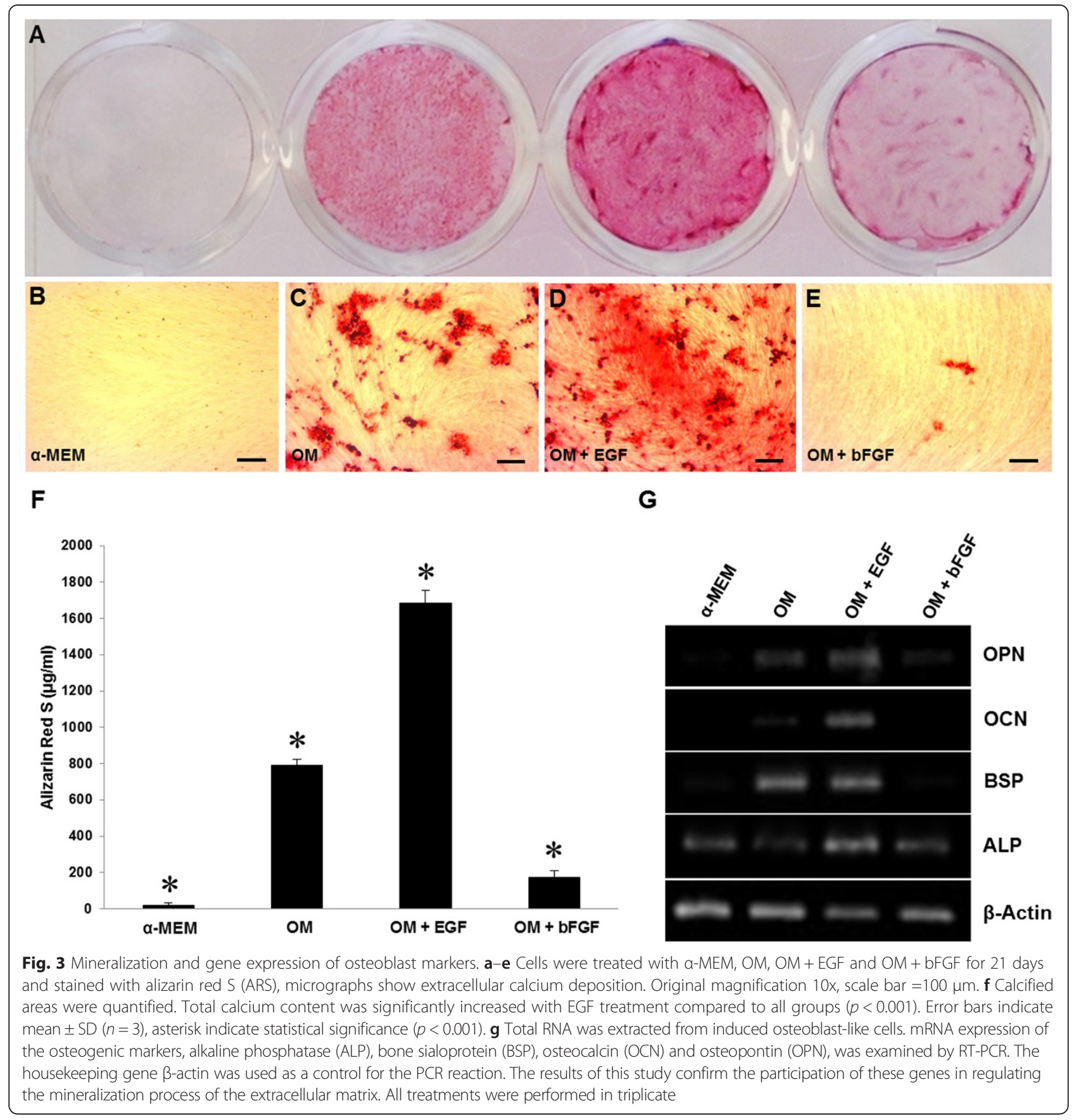

BMP-2 expression in human periodontal ligament cells (HPDLCs) [39]. Since BMPs play a critical role in the mineralization process $[40,41]$, one can predict that the supernatant cell culture of EGF-treated cells could promote osteogenic differentiation more efficiently. Based on our findings, EGF can be used alone or in combination with any of these factors to achieve a synergistic effect. It is noteworthy that previous studies with EGF do not give similar results, but sometimes observations can be antagonistic. In this respect, some studies have reported an inhibitory effect induced of EGF on osteogenic differentiation of MSCs not derived from dental pulp $[42,43]$. A possible explanation for these heterogeneous results could be variation of cell origin of MSCs used in each study. This strengthens the importance of characterizing MSCs derived from dental pulp. Another possible reason for this discrepancy is the use of primary or immortalized cells as well as their heterogeneity. In order to reduce this heterogeneity, our experiments were performed using magnetically-labelled DPSCs CD $105^{+}$ 
thus favoring the phenotype of primary cells, which could be closer to an in vivo situation than the experiments done with immortalized cells.

On the other hand, we also observed that bFGF was not able to exert effects similar to EGF and was a significant inhibitory factor for mineralization and differentiation towards osteoblast-like cells. This confirms that not all growth factors related to the proliferation and expan- sion of DPSCs are capable of enhancing osteogenic mineralization. Similarly, these effects were also observed by Li et al. [17-19] on SHED, although they evaluated a higher bFGF concentration (100 ng/ml), which is 10 times more concentrated than that of our experiments.

Cell morphology has been used as an important indicator to characterize and assess cell quality [44, 45]; we observed that morphological changes can also be used to follow mesenchymal-osteoblast cell transition from DPSCs at early stages (1 week). Here we found typical osteoblast morphology in advanced stages of cell differentiation (3 weeks) associated with high levels of calcium deposits. During the odontogenic differentiation, it is known that there is an up-regulation of odontoblast-specific genes, including dentin sialophosphoprotein (DSPP) and dentin matrix protein 1 (DMP1) [46, 47]. In our study due to dental origin of the cells is possible an odontogenic differentiation too; these results suggest that cell morphology in early stages of cell differentiation can be an important complementary data to assess cell lineage; however, in a confluent cell culture it is technically complicated to measure those morphological changes. It is noteworthy that after 1 week in osteogenic conditions, the DPSCs changed their colony-cell distribution; moreover, a greater cell adherence can be observed. As a general consensus, some surface markers are included within the minimum criteria for defining MSCs [48]; however, others markers have been associated with MSC lineage, such as CD146 and CD10, both expressed on DPSCs $[49,50]$ but their biological implication to the MSC lineage remains poorly known. Furthermore, in vitro EGF treatment was enough to reduce the expression of both cell markers, confirming an osteogenic role by EGF on DPSCs. The cell differentiation trigger changes in the immunophenotype of DPSCs, a test that can be used to monitor cell differentiation. We have found that there is a strong relationship between CD146 and CD10 expression levels and the osteogenic differentiation of DPSCs because these markers are related with the stemness of these cells. After 7 days, we observed stronger surface marker suppression with EGF but it is clear that this criterion is not enough to consider it as osteogenic differentiation; however, it can be useful to follow the
DPSC-osteoblast transition process. Nonetheless, it would be necessary to enlarge this kind of assays to characterize the behavior of other surface markers associated with the stemness of MSCs. Additionally, osteogenic in vitro differentiation of MSCs is commonly evidenced by early ALP activity, extracellular matrix mineralization and expression of typical osteoblast markers [51-53]. In agreement with our experiments, an increase of mRNA expression of ALP was observed in cells cultured with EGF. In addition, it is well known that $\mathrm{OCN}$ is an important osteogenic marker which regulates the formation of mineralization nodules and hence, leads to osteogenesis [54]. In this context, the upregulation of OCN expression as results from EGF treatment strengthen this study, suggesting its osteogenic effect. OPN, another important marker of late-stage osteoblast differentiation [55], was also overexpressed when cells were cultured with EGF, confirming its osteogenic role.

To our knowledge, this is the first report that evaluates the osteogenic effects of EGF on DPSCs; however, to elucidate the mechanism by which this occurs as well as its efficacy in animal models, further studies are required.

In conclusion, this study demonstrates that EGF plays an enhancer role on osteogenic differentiation of DPSCs because it is capable of increasing extracellular matrix mineralization. A low concentration of EGF $(10 \mathrm{ng} / \mathrm{ml})$ is sufficient to induce morphological and phenotypic changes; however, bFGF at an equal concentration exerts an inhibitory effect. These data suggests that DPSCs in combination with EGF could be an effective stem cell-based therapy to bone tissue engineering applications in periodontics and oral implantology.

\section{Competing interests}

The authors declare that they have no competing interests.

\section{Authors' contributions}

CDAM conceived the idea and designed the study; carried out cell culture experiments and drafted the manuscript; acquired and analyzed the data. YGP participated in the design and development of the experimental process; reviewed the data. APLL carried out immunocytochemistry experiments; acquired and analyzed the data. RERZ carried out PCR experiments; acquired and analyzed the data. AMJ carried out flow cytometry experiments; acquired and analyzed the data. CEMDLG participated in the design and development of experimental process; reviewed the data. MMM analysis and interpretation of data; drafted the manuscript. MADLGR analysis and interpretation of data; participated in the revision of the manuscript. All authors read and approved the final manuscript.

\section{Acknowledgments}

The first author, CDAM, thanks the Consejo Nacional de Ciencia y Tecnología (CONACYT), Mexico for funding through the PhD scholarship. All authors are grateful with Dr. José Luis Montiel Hernández and Dr. Sergio Lozano-Rodríguez for their assistance in editing the manuscript and Dr. Ismael Malagón Santiago for his help in the statistical analysis. 


\section{Funding}

This work was supported by grant Proinnova No.141616 from Esteripharma de México, S.A.de C.V., Cancer Society in Stockholm, the King Gustav V Jubilee Fund, Stockholm and The Swedish Cancer Society.

\section{Author details}

'Unidad de Odontología Integral y Especialidades, Centro de Investigación y Desarrollo en Ciencias de la Salud, Universidad Autónoma de Nuevo León, Monterrey, Nuevo León, México. ${ }^{2}$ Instituto de Biotecnología, Facultad de Ciencias Biológicas, Universidad Autónoma de Nuevo León, San Nicolás de los Garza, Nuevo León, México. ${ }^{3}$ Departamento de Química, Facultad de Ciencias Biológicas, Universidad Autónoma de Nuevo León, San Nicolás de los Garza, Nuevo León, México. ${ }^{4}$ Facultad de Odontología, Universidad Autónoma de Nuevo León, Monterrey, Nuevo León, México. ${ }^{5}$ Facultad de Medicina, Universidad Autónoma de Nuevo León, Monterrey, Nuevo León, México. ${ }^{6}$ Department of Oncology-Pathology, CCK, Karolinska Institutet, Stockholm, Sweden.

\section{Received: 17 April 2015 Accepted: 17 August 2015}

\section{Published online: 03 September 2015}

\section{References}

1. Bianco P, Robey PG. Stem cells in tissue engineering. Nature. 2001;414:118-21.

2. Pittenger MF, Mackay AM, Beck SC, Jaiswal RK, Douglas R, Mosca JD, et al. Multilineage potential of adult human mesenchymal stem cells. Science. 1999;284:143-7.

3. Gronthos S, Mankani M, Brahim J, Robey PG, Shi S. Postnatal human dental pulp stem cells (DPSCs) in vitro and in vivo. Proc Natl Acad Sci U S A. 2000;97:13625-30

4. Gronthos S, Brahim J, Li W, Fisher LW, Cherman N, Boyde A, et al. Stem cell properties of human dental pulp stem cells. J Dent Res. 2002;81:531-5.

5. Miura M, Gronthos S, Zhao M, Lu B, Fisher LW, Robey PG, et al. SHED: stem cells from human exfoliated deciduous teeth. Proc Natl Acad Sci U S A. 2003;100:5807-12.

6. Riccio M, Resca E, Maraldi T, Pisciotta A, Ferrari A, Bruzzesi G, et al. Human dental pulp stem cells produce mineralized matrix in 2D and 3D cultures. Eur J Histochem. 2010;54:e46.

7. Langenbach F, Handschel J. Effects of dexamethasone, ascorbic acid and $\beta$-glycerophosphate on the osteogenic differentiation of stem cells in vitro. Stem Cell Res Ther. 2013;4:117.

8. Yu J, He H, Tang C, Zhang G, Li Y, Wang R, et al. Differentiation potential of STRO-1+ dental pulp stem cells changes during cell passaging. BMC Cell Biol. 2010;11:32.

9. Hoemann CD, El-Gabalawy H, McKee MD. In vitro osteogenesis assays: influence of the primary cell source on alkaline phosphatase activity and mineralization. Pathol Biol. 2009;57:318-23.

10. Huang Z, Nelson ER, Smith RL, Goodman SB. The sequential expression profiles of growth factors from osteoprogenitors [correction of osteroprogenitors] to osteoblasts in vitro. Tissue Eng. 2007;13:2311-20.

11. Rodrigues $M$, Griffith $L$, Wells A. Growth factor regulation of proliferation and survival of multipotential stromal cells. Stem Cell Res Ther. 2010;1:32.

12. Carpenter G, Cohen S. Epidermal growth factor. J Biol Chem. 1990;265:7709-12

13. Mroczkowski B, Reich M, Chen K, Bell Gl, Cohen S. Recombinant human epidermal growth factor precursor is a glycosylated membrane protein with biological activity. Mol Cell Biol. 1989;9:2771-8.

14. Tamama K, Fan VH, Griffith LG, Blair HC, Wells A. Epidermal growth factor as a candidate for ex vivo expansion of bone marrow-derived mesenchymal stem cells. Stem Cells. 2006;24:686-95.

15. Tsutsumi S, Shimazu A, Miyazaki K, Pan H, Koike C, Yoshida E, et al. Retention of multilineage differentiation potential of mesenchymal cells during proliferation in response to FGF. Biochem Biophys Res Commun. 2001;288:413-9.

16. Ito T, Sawada R, Fujiwara Y, Seyama Y, Tsuchiya T. FGF-2 suppresses cellular senescence of human mesenchymal stem cells by down-regulation of TGF-beta 2. Biochem Biophys Res Commun. 2007;359:108-14.

17. Qian J, Jiayuan W, Wenkai J, Peina W, Ansheng Z, Shukai S, et al. Basic fibroblastic growth factor affects the osteogenic differentiation of dental pulp stem cells in a treatment-dependent manner. Int Endod J. 2014;48(7):690-700.
18. Osathanon T, Nowwarote N, Pavasant P. Basic fibroblast growth factor inhibits mineralization but induces neuronal differentiation by human dental pulp stem cells through a FGFR and PLCY signaling pathway. J Cell Biochem. 2011;112:1807-16.

19. Li B, Qu C, Chen C, Liu Y, Akiyama K, Yang R, et al. Basic fibroblast growth factor inhibits osteogenic differentiation of stem cells from human exfoliated deciduous teeth through ERK signaling. Oral Dis. 2012;18:285-92.

20. Osathanon T, Nowwarote N, Manokawinchoke J, Pavasant P. bFGF and JAGGED1 regulate alkaline phosphatase expression and mineralization in dental tissue-derived mesenchymal stem cells. J Cell Biochem. 2013;114:2551-61.

21. Fan VH, Tamama K, Au A, Littrell R, Richardson LB, Wright JW, et al. Tethered epidermal growth factor provides a survival advantage to mesenchymal stem cells. Stem Cells. 2007;25:1241-51.

22. Harris RC, Chung E, Coffey RJ. EGF receptor ligands. Exp Cell Res. 2003;284:2-13.

23. Schmidt MH, Furnari FB, Cavenee WK, Bogler O. Epidermal growth factor receptor signaling intensity determines intracellular protein interactions, ubiquitination, and internalization. Proc Natl Acad Sci U S A. 2003;100:6505-10.

24. Kratchmarova I, Blagoev B, Haack-Sorensen M, Kassem M, Mann M. Mechanism of divergent growth factor effects in mesenchymal stem cell differentiation. Science. 2005;308:1472-7.

25. Platt MO, Roman AJ, Wells A, Lauffenburger DA, Griffith LG. Sustained epidermal growth factor receptor levels and activation by tethered ligand binding enhances osteogenic differentiation of multi-potent marrow stromal cells. J Cell Physiol. 2009;221:306-17.

26. Stanford CM, Jacobson PA, Eanes ED, Lembke LA, Midura RJ. Rapidly forming apatitic mineral in an osteoblastic cell line (UMR 106-01 BSP). J Biol Chem. 1995;270:9420-8.

27. Sambrook J, Maccallum P, Russel D. Molecular Cloning: A Laboratory Manual. 3rd ed. Woodbury, NY: Cold Spring Harbor Press; 2001.

28. Discher DE, Mooney DJ, Zandstra PW. Growth factors, matrices, and forces combine and control stem cells. Science. 2009;324:1673-7.

29. Suzuki A, Ghayor C, Guicheux J, Magne D, Quillard S, Kakita A, et al. Enhanced expression of the inorganic phosphate transporter Pit-1 is involved in BMP-2-induced matrix mineralization in osteoblast-like cells. J Bone Miner Res. 2006;21:674-83.

30. Luppen CA, Smith E, Spevak L, Boskey AL, Frenkel B. Bone morphogenetic protein-2 restores mineralization in glucocorticoid-inhibited MC3T3-E1 osteoblast cultures. J Bone Miner Res. 2003;18:1186-97.

31. Rawadi G, Vayssière B, Dunn F, Baron R, Roman-Roman S. BMP-2 controls alkaline phosphatase expression and osteoblast mineralization by a Wnt autocrine loop. J Bone Miner Res. 2003;18:1842-53.

32. Bonnamain $V$, Thinard $R$, Sergent-Tanguy $S$, Huet $P$, Bienvenu $G$, Naveilhan $P$, et al. Human dental pulp stem cells cultured in serum-free supplemented medium. Front Physiol. 2013;4:357.

33. Tamama K, Kawasaki H, Wells A. Epidermal growth factor (EGF) treatment on multipotential stromal cells (MSCS). Possible enhancement of therapeutic potential of MSC. J Biomed Biotechnol. 2010;2010:795385.

34. Howard C, Murray PE, Namerow KN. Dental pulp stem cell migration. J Endod. 2010;36:1963-6.

35. Kim SM, Jung JU, Ryu JS, Jin JW, Yang HJ, Ko K, et al. Effects of gangliosides on the differentiation of human mesenchymal stem cells into osteoblasts by modulating epidermal growth factor receptors. Biochem Biophys Res Commun. 2008;371:866-71.

36. Huang $\mathrm{CH}$, Tseng WY, Yao CC, Jeng JH, Young TH, Chen YJ. Glucosamine promotes osteogenic differentiation of dental pulp stem cells through modulating the level of the transforming growth factor-beta type I receptor. J Cell Physiol. 2010;225:140-51.

37. Feng X, Huang D, Lu X, Feng G, Xing J, Lu J, et al. Insulin-like growth factor 1 can promote proliferation and osteogenic differentiation of human dental pulp stem cells via mTOR pathway. Dev Growth Differ. 2014;56:615-24.

38. Feng X, Feng G, Xing J, Shen B, Li L, Tan W, et al. TNF-a triggers osteogenic differentiation of human dental pulp stem cells via the NF-KB signalling pathway. Cell Biol Int. 2013;37:1267-75.

39. Teramatsu Y, Maeda H, Sugii H, Tomokiyo A, Hamano S, Wada N, et al. Expression and effects of epidermal growth factor on human periodontal ligament cells. Cell Tissue Res. 2014;357:633-43.

40. Devescovi V, Leonardi E, Ciapetti G, Cenni E. Growth factors in bone repair. Chir Organi Mov. 2008;92:161-8.

41. Chen D, Zhao M, Mundy GR. Bone morphogenetic proteins. Growth Factors. 2004;22:233-41. 
42. Krampera M, Pasini A, Rigo A, Scupoli MT, Tecchio C, Malpeli G, et al. HB-EGF/HER-1 signaling in bone marrow mesenchymal stem cells: inducing cell expansion and reversibly preventing multilineage differentiation. Blood. 2005;106:59-66.

43. Hu F, Wang X, Liang G, Lv L, Zhu Y, Sun B, et al. Effects of epidermal growth factor and basic fibroblast growth factor on the proliferation and osteogenic and neural differentiation of adipose-derived stem cells. Cell Rep. 2013;15:224-32.

44. Matsuoka F, Takeuchi I, Agata H, Kagami H, Shiono H, Kiyota Y, et al. Morphology-based prediction of osteogenic differentiation potential of human mesenchymal stem cells. PLoS One. 2013;8:e55082.

45. Leischner U, Schierloh A, Zieglgansberger W, Dodt HU. Formalin-induced fluorescence reveals cell shape and morphology in biological tissue samples. PLoS One. 2010;5:e10391.

46. Nam S, Won JE, Kim CH, Kim HW. Odontogenic differentiation of human dental pulp stem cells stimulated by the calcium phosphate porous granules. J Tissue Eng. 2011;2011:812547.

47. Sun HL, Wu YR, Huang C, Wang JW, Fu DJ, Liu YC. The effect of SIRT6 on the odontoblastic potential of human dental pulp cells. J Endod. 2014;40:393-8

48. Dominici M, Le Blanc K, Mueller I, Slaper-Cortenbach I, Marini F, Krause D, et al. Minimal criteria for defining multipotent mesenchymal stromal cells. The International Society for Cellular Therapy position statement. Cytotherapy. 2006;8:315-7.

49. Gronthos S, Franklin DM, Leddy HA, Robey PG, Storms RW, Gimble JM. Surface protein characterization of human adipose tissue-derived stromal cells. J Cell Physiol. 2001;189:54-63.

50. Vishwanath VR, Nadig RR, Nadig R, Prasanna JS, Karthik J, Pai VS. Differentiation of isolated and characterized human dental pulp stem cells and stem cells from human exfoliated deciduous teeth: An in vitro study. J Conserv Dent. 2013;16:423-8.

51. Mori G, Brunetti G, Oranger A, Carbone C, Ballini A, Lo Muzio L, et al. Dental pulp stem cells: osteogenic differentiation and gene expression. Ann N Y Acad Sci. 2011;1237:47-52.

52. Stucki U, Schmid J, Hämmerle CF, Lang NP. Temporal and local appearance of alkaline phosphatase activity in early stages of guided bone regeneration. A descriptive histochemical study in humans. Clin Oral Implants Res. 2001;12:121-7.

53. Ling LE, Feng L, Liu HC, Wang DS, Shi ZP, Wang JC, et al. The effect of calcium phosphate composite scaffolds on the osteogenic differentiation of rabbit dental pulp stem cells. J Biomed Mater Res A. 2015;103:1732-45.

54. Shi X, Wang Y, Varshney RR, Ren L, Zhang F, Wang DA. In-vitro osteogenesis of synovium stem cells induced by controlled release of bisphosphate additives from microspherical mesoporous silica composite. Biomaterials. 2009;30:3996-4005.

55. McKee MD, Addison WN, Kaartinen MT. Hierarchies of extracellular matrix and mineral organization in bone of the craniofacial complex and skeleton. Cells Tissues Organs. 2005;181:176-88.

\section{Submit your next manuscript to BioMed Central and take full advantage of:}

- Convenient online submission

- Thorough peer review

- No space constraints or color figure charges

- Immediate publication on acceptance

- Inclusion in PubMed, CAS, Scopus and Google Scholar

- Research which is freely available for redistribution 